Check for updates

Cite this: RSC Adv., 2018, 8, 7883

Received 3rd January 2018

Accepted 14th February 2018

DOI: $10.1039 / \mathrm{c} 8 \mathrm{ra00041g}$

rsc.li/rsc-advances

\title{
Highly sensitive determination of lead(II) and cadmium(II) by a large surface area mesoporous alumina modified carbon paste electrode
}

\author{
Xinyu Zheng, ${ }^{\text {a }}$ Shen Chen, ${ }^{a}$ Jiebo Chen, ${ }^{a}$ Yuheng Guo, ${ }^{b}$ Jun Peng, ${ }^{a}$ Xuechou Zhou, ${ }^{a}$ \\ Rixin LV, ${ }^{a}$ Jiandi Lin ${ }^{a}$ and Ruiyu Lin (ID *a
}

\begin{abstract}
Nanosized mesoporous $\gamma$-alumina $\left(\mathrm{M}-\gamma-\mathrm{Al}_{2} \mathrm{O}_{3}\right)$ was first prepared and then modified into a carbon paste to fabricate a novel modified carbon paste electrode. The prepared alumina has pores with an amorphous wall and large surface area. The electrochemical behavior of the modified carbon paste electrode was investigated using cyclic voltammetry (CV) and electrochemical impedance spectroscopy (EIS) methods. The modified carbon paste electrode was employed to determine $\mathrm{Pb}^{2+}$ and $\mathrm{Cd}^{2+}$ simultaneously by a differential pulse voltammetry (DPV) method. Amperometric determination was carried out in $0.1 \mathrm{~mol} \mathrm{~L}^{-1} \mathrm{NaAc}-\mathrm{HAc}$ buffer solution ( $\mathrm{pH}$ 6.0) after enriching for $360 \mathrm{~s}$ at $-1.0 \mathrm{~V}$. The oxidation peak currents of $\mathrm{Pb}^{2+}$ and $\mathrm{Cd}^{2+}$ were proportional to their concentration in the range of $0.001-10 \mu \mathrm{mol} \mathrm{L^{-1 }}$

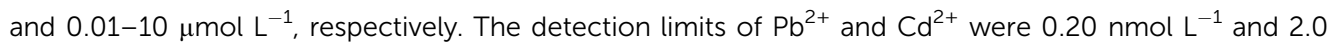
$n m o l L^{-1}(S / N=3)$, respectively. The modified carbon paste electrode shows good stability, repeatability and sensitivity. The proposed method was applied to the determination of $\mathrm{Pb}^{2+}$ and $\mathrm{Cd}^{2+}$ in water samples with satisfactory results.
\end{abstract}

\section{Introduction}

Lead and cadmium are both toxic heavy metal elements. Because of their toxicity and non-biodegradability, they can not only be accumulated in the body and endanger human health, but also cause serious pollution to the environment..$^{1-3}$ Consequently, knowledge of the quantities of $\mathrm{Pb}^{2+}$ and $\mathrm{Cd}^{2+}$ in environmental samples has important practical significance. At present, various analytical techniques have been reported for the determination of $\mathrm{Pb}^{2+}$ and $\mathrm{Cd}^{2+}$ at low concentrations, such as atomic fluorescence spectrometry, ${ }^{4,5}$ atomic absorption spectroscopy, ${ }^{6,7}$ inductively coupled plasma mass spectrometry, ${ }^{8,9}$ and high performance liquid chromatography. ${ }^{10}$ Although these techniques have good selectivity and high sensitivity, most of the above techniques require relatively ponderous and complicated instruments and are timeconsuming, in particular for the in situ analysis of metal ions. In contrast, electrochemical voltammetry is widely used for trace heavy metal ion analysis and on-site testing because of its low-cost instruments and equipment, high sensitivity, wide detection range, rapid performance and high portability.

The carbon paste electrodes have the advantages of simple preparation, non-toxicity, chemical inertness, very stable

${ }^{a}$ School of Life Sciences, Fujian Agriculture and Forestry University, Fuzhou, Fujian, 350002, China.E-mail: mailto:zhengxinyu0621@sina.com; zhengxinyu0621@sina. com; ruiyulin121011@sina.com

${ }^{b}$ College of Chemistry, Fuzhou University, Fuzhou, Fujian, 350116, China electrochemical response, easy updating the surface, long operational lifetime and low background current. ${ }^{11,12}$ Owing to these advantages, carbon paste electrodes have become one of the most popular electrode materials. The selectivity and sensitivity of the carbon paste electrodes may be improved by adding special modifiers to the carbon paste. ${ }^{13}$ However, it is still a challenging requirement to design or synthesize a new type of modifier for higher selectivity and sensitivity.

Mesoporous materials, such as Ni-ZSM-5, Ni-SBA-15, Cuzeolite and Pb-zeolite, were widely applied in catalysts, sensors and energy storage due to their high specific surface area, large pore volume, narrow pore size distribution, tunable pore size and favorable stability. ${ }^{14-17}$ Research indicates that $\mathrm{M}-\gamma-\mathrm{Al}_{2} \mathrm{O}_{3}$ can raise the electrode conductivity, the electron transfer and can also enhance the analytical sensitivity due to their large surface areas. Up to now, many electrochemical sensors have been reported based on $\mathrm{M}-\gamma-\mathrm{Al}_{2} \mathrm{O}_{3}$ with ordinary structure for the determination of sodium aerosol, nicotinamide adenine dinucleotide, amitriptyline, captopril, ascorbic acid, dopamine and uric acid, and so on. ${ }^{18-20}$

Many approaches have been used to synthesize large surface area mesoporous alumina with the P123 as a structuredirecting agent. ${ }^{21,22}$ The high surface area alumina are prepared via mainly controlled the $\mathrm{Al}^{3+}$ hydrolysis speed by regulating $\mathrm{pH}$ value and reducing the concentrations of anions in the reaction system to disturb the self-assembly process. ${ }^{23-25}$ In process of the synthesis, the added aniline could not only regulate the $\mathrm{pH}$ value of the reaction system to control the $\mathrm{Al}^{3+}$ 


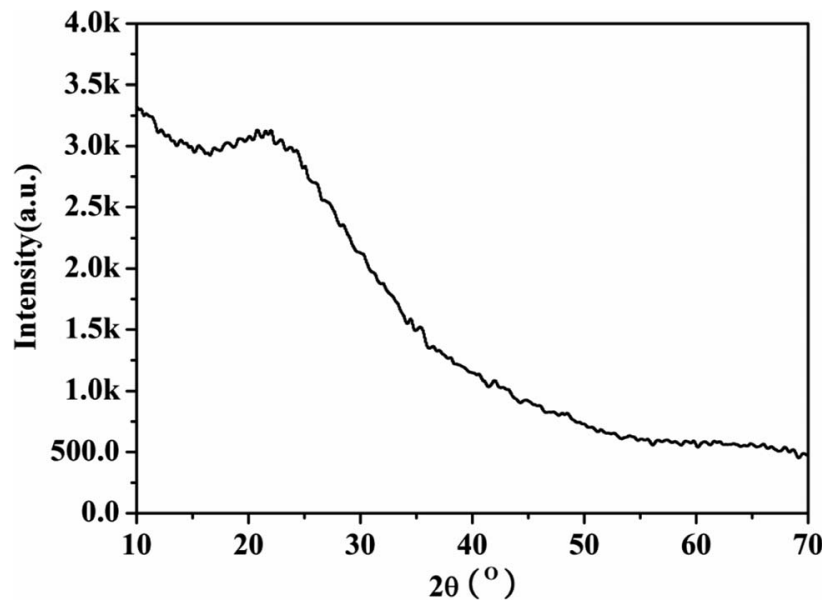

Fig. 1 The PXRD spectrum of the large surface area $\mathrm{M}-\gamma-\mathrm{Al}_{2} \mathrm{O}_{3}$.

hydrolysis speed, but also could protect the aluminum ions at the organic-inorganic interface from being affected by the chloride ions of the reaction system. So in present work, aniline was chosen as an interface protective agent to prepare large surface area mesoporous alumina which was employed to modify the carbon paste. The as-prepared large surface area mesoporous alumina modified carbon paste was used to prepare modified carbon paste electrode. The prepared $\mathrm{M}-\gamma$ $\mathrm{Al}_{2} \mathrm{O}_{3}$ was characterized by powder X-ray diffraction (PXRD), transmission electron microscopy (TEM) and BrunauerEmmett-Teller (BET) analysis. Cyclic voltammetry (CV) and electrochemical impedance spectroscopy (EIS) methods were utilized to study the electrochemical behavior of the novel working electrode. A DPV method was developed for the simultaneous determination of $\mathrm{Pb}^{2+}$ and $\mathrm{Cd}^{2+}$. The results show that the modified carbon paste electrode has excellent sensitivity, wide linear range, low detection limit, favorable stability and reproducibility. Finally, the modified carbon

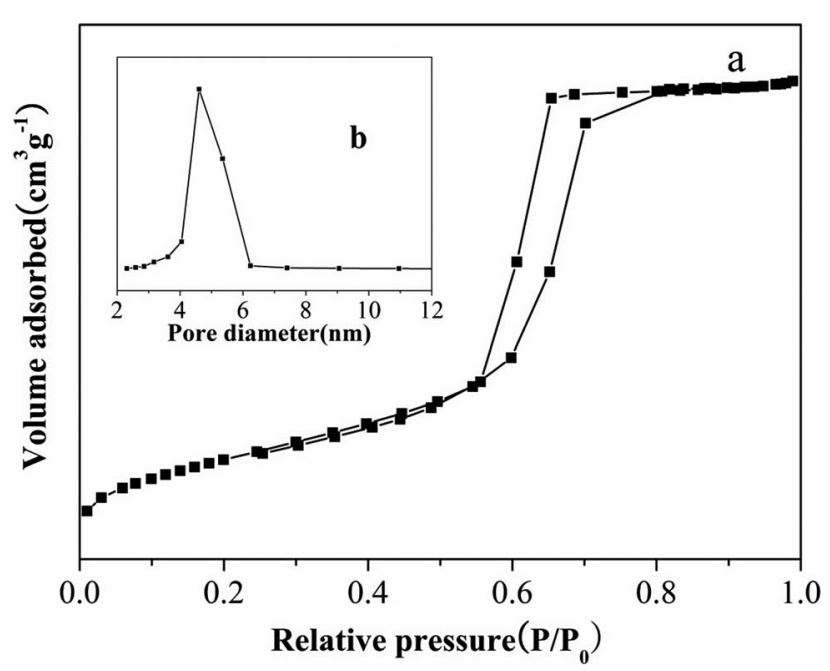

Fig. 2 (a) Nitrogen adsorption-desorption isotherm and (b) pore-size distribution of the large surface area $\mathrm{M}-\gamma-\mathrm{Al}_{2} \mathrm{O}_{3}$.

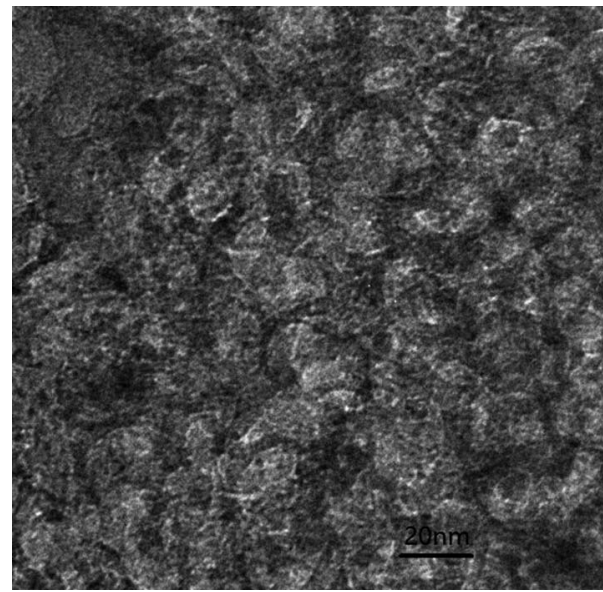

Fig. 3 The TEM image of the large surface area $\mathrm{M}-\gamma-\mathrm{Al}_{2} \mathrm{O}_{3}$

paste electrode was successfully applied to the determination of $\mathrm{Pb}^{2+}$ and $\mathrm{Cd}^{2+}$ in water samples.

\section{Experimental}

\subsection{Apparatus}

The CHI660D Electrochemical Workstation (Shanghai Chenhua Instruments, Shanghai, China) was used to perform the electrochemical measurements. The three electrodes electrochemical cell contain an unmodified or modified carbon paste electrode with a diameter of $3.0 \mathrm{~mm}$ and $5.0-6.0 \mathrm{~mm}$ in depth (working electrode), a platinum electrode (auxiliary electrode) and $\mathrm{Ag} / \mathrm{AgCl} / \mathrm{sat}$. $\mathrm{KCl}$ electrode (reference electrode). Powder X-ray diffraction (PXRD) analysis was conducted by a PANalytical X'pert diffractometer with $\mathrm{Cu} \mathrm{K} \alpha(1.5418 \AA)$ radiation generated at $40 \mathrm{kV}$ and $40 \mathrm{~mA}$. The surface area (calculated by

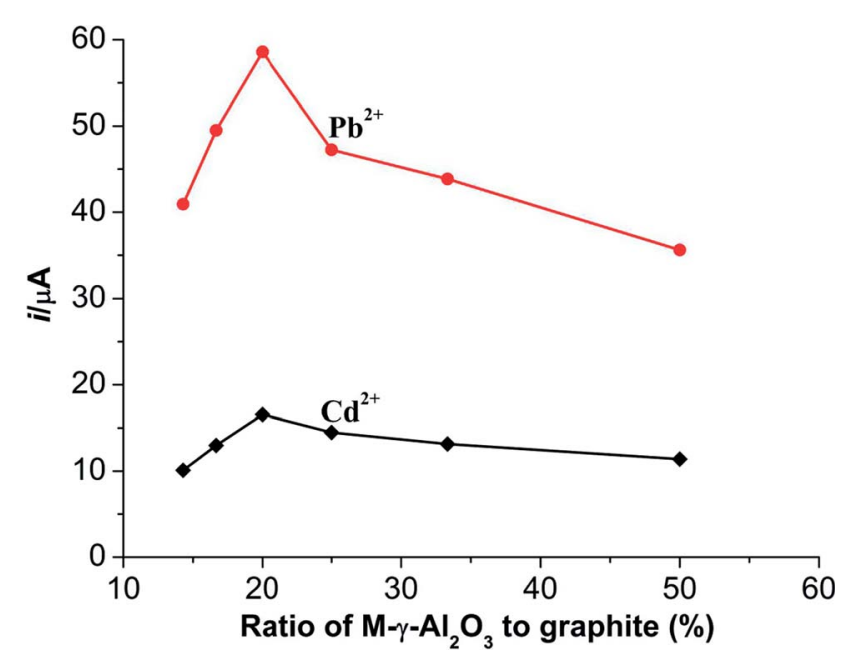

Fig. 4 Influences of different mass ratios $\left(\mathrm{M}-\gamma-\mathrm{Al}_{2} \mathrm{O}_{3}\right.$ to graphite powder) on the current responses of $10 \mu \mathrm{mol} \mathrm{L}{ }^{-1} \mathrm{Cd}^{2+}$ and $10 \mu \mathrm{mol}$ $\mathrm{L}^{-1} \mathrm{~Pb}^{2+}$. Supporting electrolyte: $0.1 \mathrm{~mol} \mathrm{~L}^{-1} \mathrm{NaAc}-\mathrm{HAc}$ buffer solution ( $\mathrm{pH} 4.5$ ); accumulation potential: $-1.0 \mathrm{~V}$; accumulation time: $180 \mathrm{~s}$; pulse amplitude: $0.05 \mathrm{~V}$; pulse width: $0.05 \mathrm{~s}$; pulse period: $0.2 \mathrm{~s}$. 

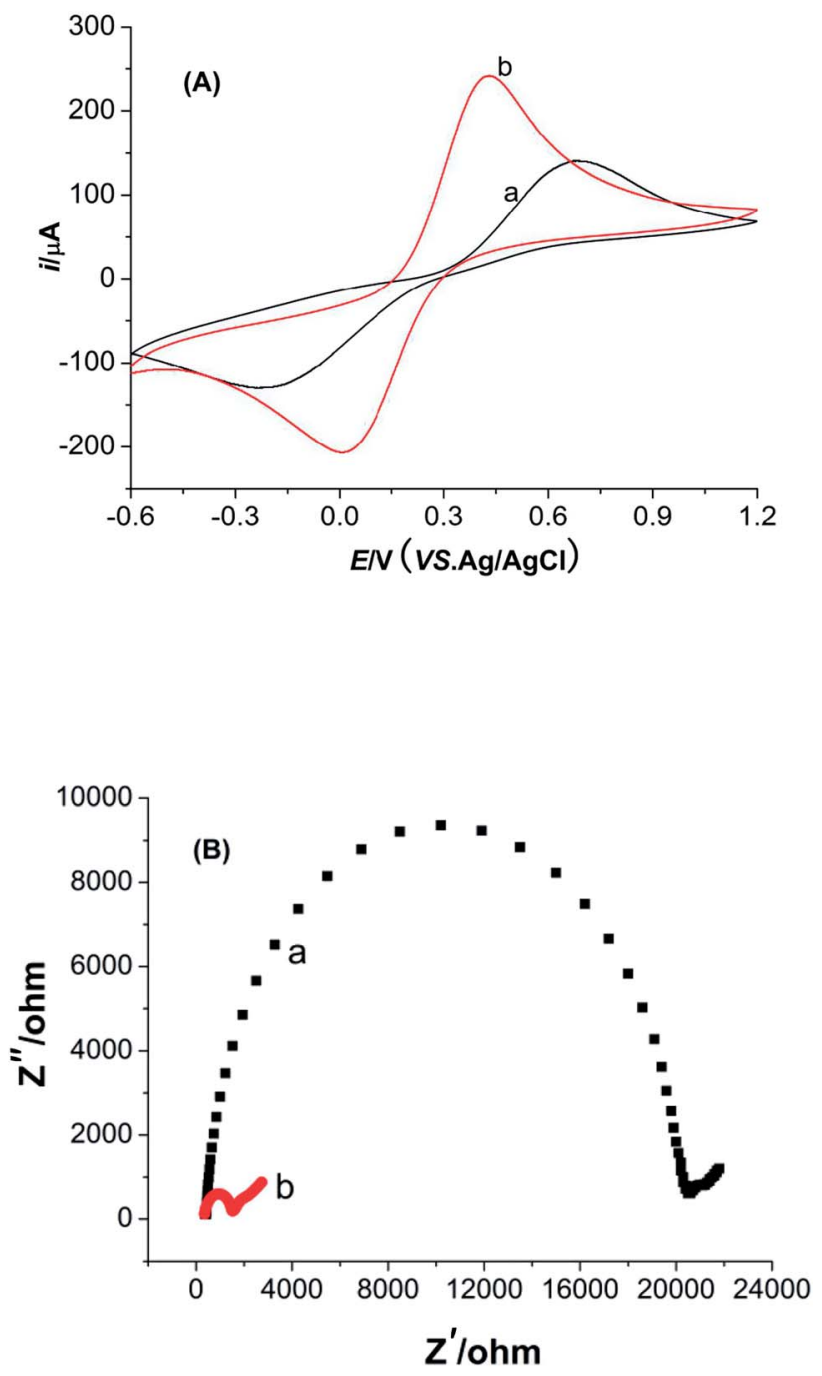

Fig. 5 (A) $\mathrm{CV}$ s of $\mathrm{BCPE}$ (curve a) and $\mathrm{M}-\gamma-\mathrm{Al}_{2} \mathrm{O}_{3}-\mathrm{CPE}$ (curve b) in $5.0 \mathrm{mmol} \mathrm{L} \mathrm{L}^{-1} \mathrm{~K}_{4}\left[\mathrm{Fe}(\mathrm{CN})_{6}\right] / \mathrm{K}_{3}\left[\mathrm{Fe}(\mathrm{CN})_{6}\right] \quad(1: 1)$ solution containing $0.1 \mathrm{~mol} \mathrm{~L}^{-1} \mathrm{KCl}$. Scan rate: $100 \mathrm{mV} \mathrm{s}^{-1}$. (B) Nyquist plots of EIS in $5.0 \mathrm{mmol} \mathrm{L} \mathrm{L}^{-1} \mathrm{~K}_{4}\left[\mathrm{Fe}(\mathrm{CN})_{6}\right] / \mathrm{K}_{3}\left[\mathrm{Fe}(\mathrm{CN})_{6}\right] \quad(1: 1)$ solution containing $0.1 \mathrm{~mol} \mathrm{~L}{ }^{-1} \mathrm{KCl}$ for $\mathrm{BCPE}$ (curve a) and $\mathrm{M}-\gamma-\mathrm{Al}_{2} \mathrm{O}_{3}-\mathrm{CPE}$ (curve b). Ac voltage: $5 \mathrm{mV}$; frequency range: $0.1-10 \mathrm{MHz}$.

BET method), pore size distribution (calculated by BJH method) and pore volume were obtained at $-196{ }^{\circ} \mathrm{C}$ using an Ominsorp 100cx analyzer (Micromeritics Tristar, USA). Transmission electron microscopy (TEM) images were acquired by a JEM 2100 electron microscope operating at an accelerating voltage of 200 $\mathrm{kV}$.

\subsection{Chemicals and materials}

$\mathrm{Pb}\left(\mathrm{NO}_{3}\right)_{2}, \mathrm{Cd}\left(\mathrm{NO}_{3}\right)_{2} \cdot 4 \mathrm{H}_{2} \mathrm{O}, \mathrm{Al}_{2} \mathrm{O}_{3}$, graphite powder, liquid paraffin, aniline and aluminum isopropoxide were bought from Sinopharm Chemical Reagent Co., Ltd. Pluronic P123 (Mav = 5800, $\mathrm{EO}_{20} \mathrm{PO}_{70} \mathrm{EO}_{20}$ ) was obtained from Aldrich Chemical Company (Shanghai, China). Other reagents were analytical grades and purchased from local commercial sources. Buffer solution was prepared by mixing $0.1 \mathrm{~mol} \mathrm{~L}^{-1} \mathrm{NaAc}$ and $0.1 \mathrm{~mol} \mathrm{~L}^{-1} \mathrm{HAc}$ solutions to form a $0.1 \mathrm{~mol} \mathrm{~L}^{-1} \mathrm{NaAc}-\mathrm{HAc}$ buffer solution. Distilled water was used for the preparation of all solutions and for washing. Both standard solution and buffer solutions were kept in a $4{ }^{\circ} \mathrm{C}$ refrigerator.

\subsection{Preparation of large surface area $\mathrm{M}-\gamma-\mathrm{Al}_{2} \mathrm{O}_{3}$}

In order to prepare the large surface area $\mathrm{M}-\gamma-\mathrm{Al}_{2} \mathrm{O}_{3}$, a delicate procedure should be designed. Firstly, $1 \mathrm{~g}$ of Pluronic P123 was dissolved in $20 \mathrm{~mL}$ of the absolute ethanol to form a solution. Then quantitative aluminum isopropoxide, $\mathrm{HCl}$ and aniline were added successively to the solution. This mixture was stirred at room temperature until the entire solid was dissolved completely. Consequently, a homogeneous sol was obtained. Secondly, the homogeneous sol was transferred to an oven. The solvent was evaporated with a temperature at $40{ }^{\circ} \mathrm{C}$ for $48 \mathrm{~h}$ to prepare a gel product. After that, the gel product was dried at $100{ }^{\circ} \mathrm{C}$ for $24 \mathrm{~h}$. Finally, the as-prepared sample was calcined at $400{ }^{\circ} \mathrm{C}$ in a muffle furnace with a heating rate of $10{ }^{\circ} \mathrm{C} \mathrm{min}{ }^{-1}$ and held for $3 \mathrm{~h}$ at the maximum calcination temperature. The large surface area $\mathrm{M}-\gamma-\mathrm{Al}_{2} \mathrm{O}_{3}$ was synthesized successfully after the above steps.

\subsection{Preparation of modified carbon paste electrode}

The modified carbon paste electrode was prepared as following process. $\mathrm{M}-\gamma-\mathrm{Al}_{2} \mathrm{O}_{3}$, graphite powder and liquid paraffin were mixed together in definite proportions. The mixture was grinded for about 10 minutes to get a homogenous carbon paste. Small amount of the obtained carbon paste was taken to pack tightly into the tip cavity of a carbon paste electrode. This electrode is defined as $\mathrm{M}-\gamma-\mathrm{Al}_{2} \mathrm{O}_{3}$-CPE. For comparison purpose, bare carbon paste electrode (BCPE) can be manufactured by the similar way without adding $\mathrm{M}-\gamma-\mathrm{Al}_{2} \mathrm{O}_{3}$. Smooth surfaces of $\mathrm{M}-\gamma-\mathrm{Al}_{2} \mathrm{O}_{3}-\mathrm{CPE}$ and BCPE can be obtained by polishing the electrodes on a weighting paper.

\subsection{Electrochemical measurements}

DPV method was carried out in a $10 \mathrm{~mL}$ volume of electrochemical cell containing $0.1 \mathrm{~mol} \mathrm{~L}^{-1} \mathrm{NaAc}-\mathrm{HAc}$ buffer solution (pH 6.0) as supporting electrolyte medium. The accumulation potential of $\mathrm{Pb}^{2+}$ and $\mathrm{Cd}^{2+}$ is $-1.0 \mathrm{~V}$ with an accumulation time of $360 \mathrm{~s}$. The optimum conditions of DPV method were determined. The potential ranges from -1.2 to $0 \mathrm{~V}$. The pulse amplitude, the pulse width and the scan rate are $50 \mathrm{mV}, 50 \mathrm{~ms}$ and $100 \mathrm{mV} \mathrm{s}^{-1}$, respectively. The calibration curves were obtained by plotting the peak current versus the $\mathrm{Pb}^{2+}$ and $\mathrm{Cd}^{2+}$ concentration. All electroanalytical measurements were conducted at room temperature.

\section{Results and discussion}

\subsection{Characterization of $\mathrm{M}-\gamma-\mathrm{Al}_{2} \mathrm{O}_{3}$}

The PXRD pattern of large surface area $\mathrm{M}-\gamma-\mathrm{Al}_{2} \mathrm{O}_{3}$ is shown in Fig. 1. Only one flat peak can be found at $24^{\circ}$, which demonstrates the crystallinity of $\mathrm{M}-\gamma-\mathrm{Al}_{2} \mathrm{O}_{3}$ is low and the $\mathrm{M}-\gamma-\mathrm{Al}_{2} \mathrm{O}_{3}$ has pores with amorphous wall according to Yang et al. ${ }^{26}$ Fig. 2 shows the nitrogen adsorption-desorption isotherms and pore size distribution curve of the $\mathrm{M}-\gamma-\mathrm{Al}_{2} \mathrm{O}_{3}$. The synthetic $\mathrm{M}-\gamma-\mathrm{Al}_{2} \mathrm{O}_{3}$ 


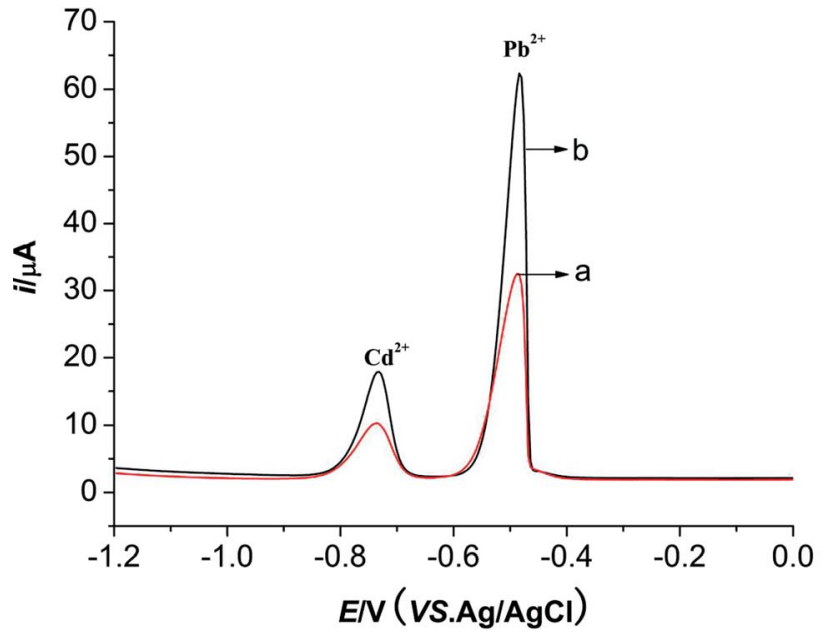

Fig. 6 DPVs of $\mathrm{Pb}^{2+}$ and $\mathrm{Cd}^{2+}$ for $\mathrm{BCPE}$ (curve a) and $\mathrm{M}-\gamma-\mathrm{Al}_{2} \mathrm{O}_{3}-\mathrm{CPE}$ (curve b). Electrochemical conditions are the same as Fig. 4.

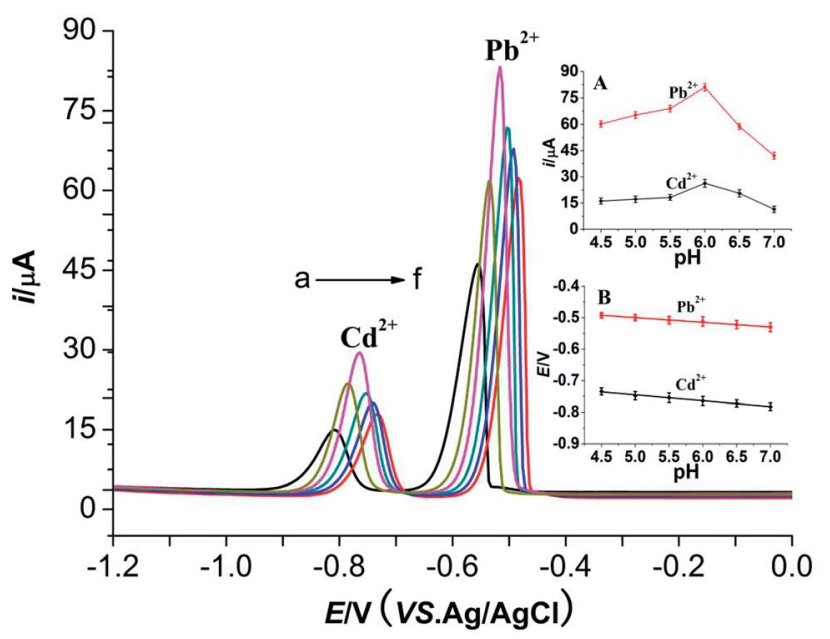

Fig. 7 Effect of different $\mathrm{pH}$ on $10 \mu \mathrm{mol} \mathrm{L}{ }^{-1} \mathrm{Cd}^{2+}$ and $10 \mu \mathrm{mol} \mathrm{L}{ }^{-1} \mathrm{~Pb}^{2+}$ at a $\mathrm{M}-\mathrm{Al}_{2} \mathrm{O}_{3}$ modified carbon paste electrode. Inset (A): plots of $i \mathrm{vs}$. $\mathrm{pH}$ for $\mathrm{Pb}^{2+}$ and $\mathrm{Cd}^{2+}$, respectively. Inset $(\mathrm{B})$ : plots of $i$ vs. $\mathrm{pH}$ for $\mathrm{Pb}^{2+}$ and $\mathrm{Cd}^{2+}$, respectively. $\mathrm{pH}: \mathrm{a}-7.0, \mathrm{~b}-6.5, \mathrm{c}-6.0, \mathrm{~d}-5.5, \mathrm{e}-5.0, \mathrm{f}-$ 4.5; other conditions are the same as Fig. 4.

shows type IV curve with hysteresis loop at high pressure, which implies the existence of mesoporous pores. The isotherms exhibit distinct capillary condensation steps, indicating uniform mesoporosity. The synthetic $\mathrm{M}-\gamma-\mathrm{Al}_{2} \mathrm{O}_{3}$ possesses a large surface area of $522 \mathrm{~m}^{2} \mathrm{~g}^{-1}$, a pore volume of $0.38 \mathrm{~cm}^{3} \mathrm{~g}^{-1}$, and a narrow poresize distribution centered at $4.9 \mathrm{~nm}$. The TEM image of large surface area $\mathrm{M}-\gamma-\mathrm{Al}_{2} \mathrm{O}_{3}$ is shown in Fig. 3. The image reveals that the sample has lath-like appearance without significant order of pore arrangement. The grain diameters of sample are in the range of $10-20 \mathrm{~nm}$. Hence, the very weak intensity of these diffraction peaks in the PXRD patterns for the sample could be attributed to their nanosized structure.

The improved surface area and comparable narrow pore size distribution were obtained compared with the prior literatures $^{21,27,28}$ which used the P123 as a structure-directing agent for
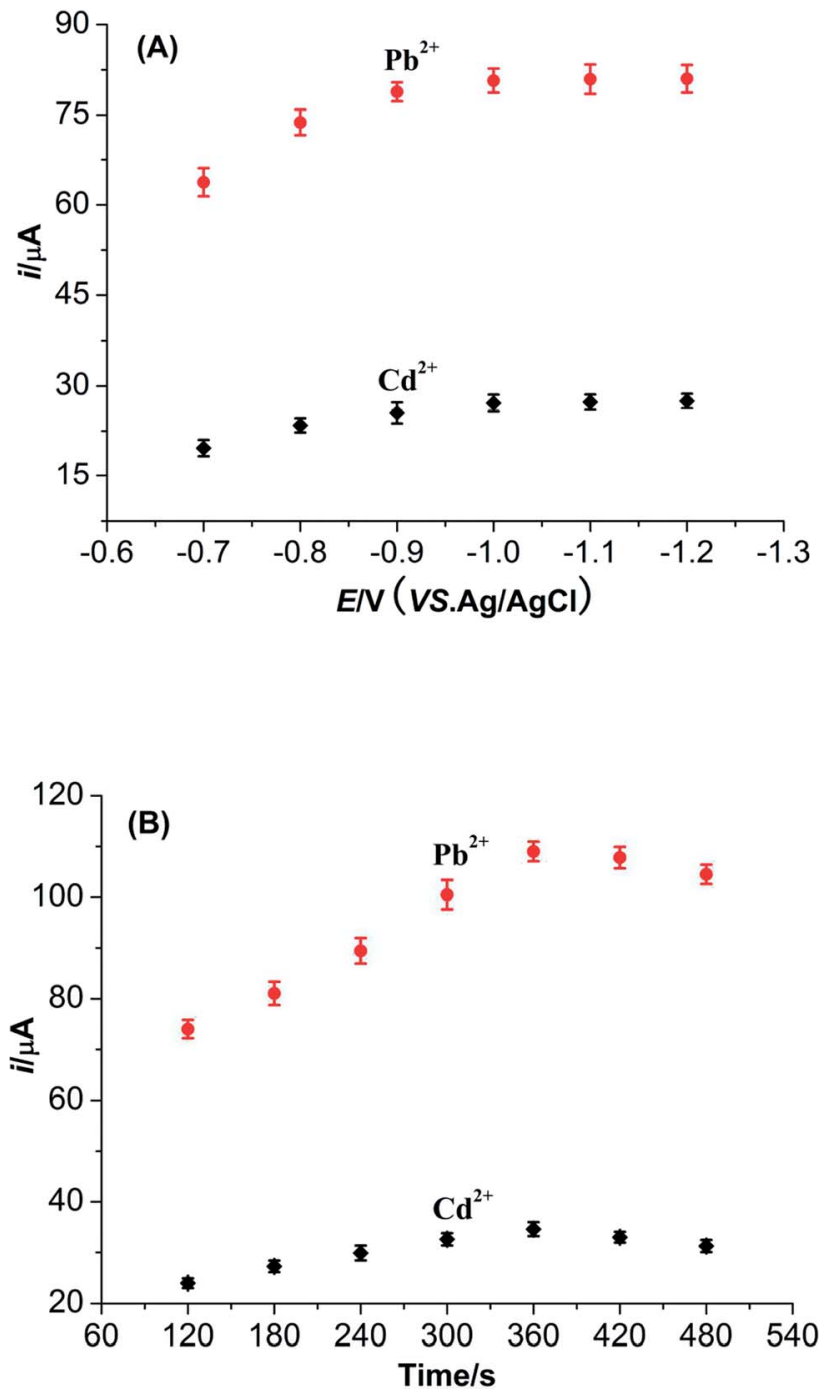

Fig. 8 (A) Influence of accumulation potential on the peak currents of $\mathrm{Pb}^{2+}$ and $\mathrm{Cd}^{2+}$. (B) Influence of accumulation time on the peak currents of $\mathrm{Pb}^{2+}$ and $\mathrm{Cd}^{2+}$.

synthesizing the $\mathrm{M}-\gamma-\mathrm{Al}_{2} \mathrm{O}_{3}$. In the synthesis system of mesoporous alumina synthesized by sol-gel method, the $\mathrm{Cl}^{-}$from the acidity adjustment will be coordinated with $\mathrm{Al}^{3+}$, and the charge balance between the organic template and inorganic aluminum will be destroyed, thus interfere the self-assembly process. The addition of aniline can coordinate with $\mathrm{Al}^{3+}$ and inhibit the coordination between them, thus promoting mesoporous structure formation. Therefore, it is considered that aniline is an interfacial protective agent for forming mesoporous alumina. ${ }^{29-31}$ So aniline was chosen as interface protective agent to prepare the mesoporous alumina with large surface area. The synthetic $\mathrm{M}-\gamma$ $\mathrm{Al}_{2} \mathrm{O}_{3}$ promise its potential application in the field of modified electrode.

\subsection{The modified proportion of mesoporous alumina}

The mass ratio of the solid mixture (graphite powder and $\mathrm{M}-\gamma$ $\mathrm{Al}_{2} \mathrm{O}_{3}$ ) to liquid paraffin was fixed as $3: 1$. Influences of different 


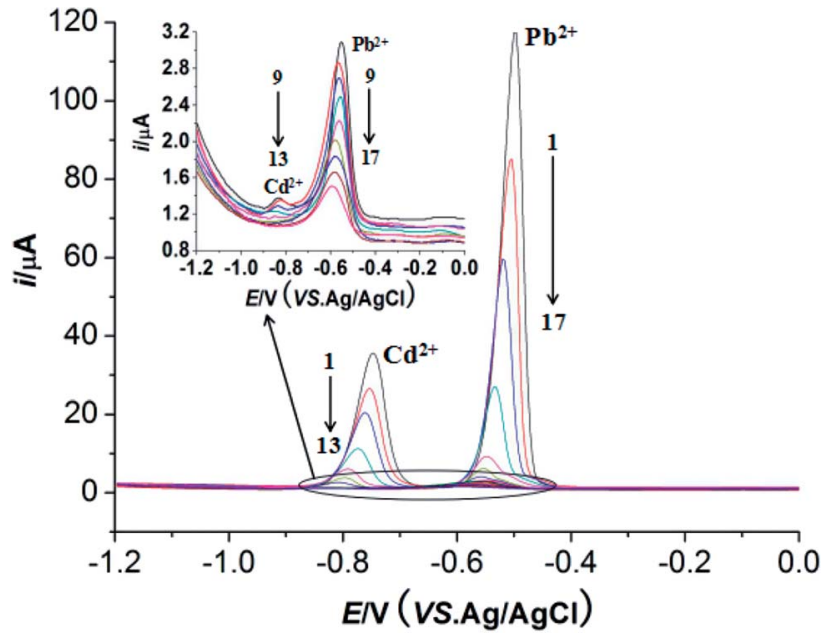

Fig. 9 DPVs of of $\mathrm{Pb}^{2+}$ and $\mathrm{Cd}^{2+}$ with different concentrations at the $\mathrm{M}-\gamma-\mathrm{Al}_{2} \mathrm{O}_{3}-\mathrm{CPE}$. Supporting electrolyte: $0.1 \mathrm{~mol} \mathrm{~L}{ }^{-1} \mathrm{NaAc}-\mathrm{HAc}$ buffer solution ( $\mathrm{pH}$ 6.0); accumulation time $360 \mathrm{~s}$; concentrations of $\mathrm{Pb}^{2+}$ (from $1 \rightarrow$ 17): 10, 7.5, 5.0, 2.5, 1.0, 0.75, 0.5, 0.25, 0.1, 0.075, 0.05, $0.025,0.01,0.0075,0.005,0.0025,0.001 \mu \mathrm{mol} \mathrm{L} \mathrm{L}^{-1}$ concentrations of $\mathrm{Cd}^{2+}(1 \rightarrow 13): 10,7.5,5.0,2.5,1.0,0.75,0.5,0.25,0.1,0.075,0.05$, $0.025,0.01 \mu \mathrm{mol} \mathrm{L}{ }^{-1}$. Other conditions are the same as Fig. 4.

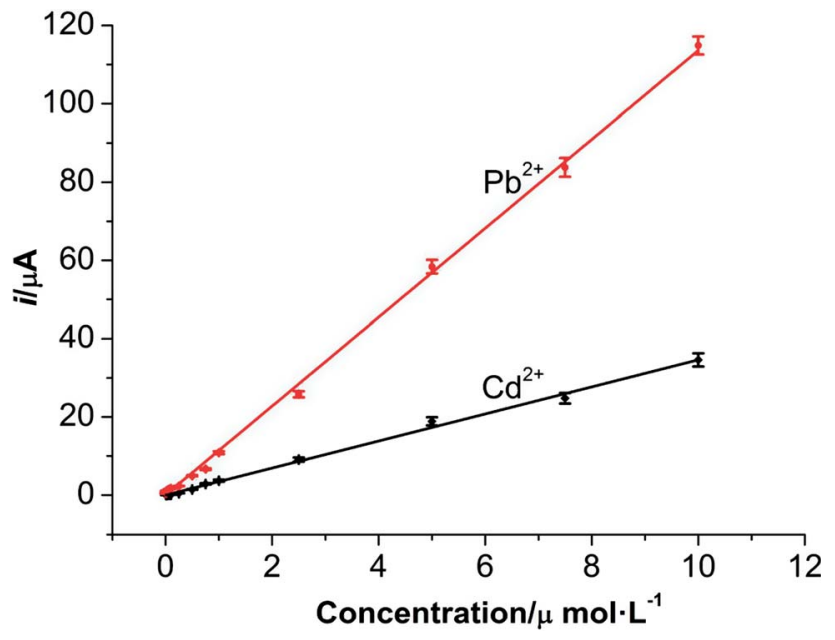

Fig. 10 The relationships between the concentrations and current responses of $\mathrm{Pb}^{2+}$ and $\mathrm{Cd}^{2+}$ at the $\mathrm{M}-\gamma-\mathrm{Al}_{2} \mathrm{O}_{3}-\mathrm{CPE}$.

mass ratios $\left(\mathrm{M}-\gamma-\mathrm{Al}_{2} \mathrm{O}_{3}\right.$ to graphite powder) on the current responses of $\mathrm{Pb}^{2+}$ and $\mathrm{Cd}^{2+}$ were well investigated. The results are shown in Fig. 4. The current responses of $\mathrm{Pb}^{2+}$ and $\mathrm{Cd}^{2+}$ enhance gradually to a maximum value and then decrease with the increasing proportion of $\mathrm{M}-\gamma-\mathrm{Al}_{2} \mathrm{O}_{3}$. As can be known in Fig. 4, the optimal mass ratio of $\mathrm{M}-\gamma-\mathrm{Al}_{2} \mathrm{O}_{3}$ to graphite powder is $1: 4$. The probably reasons may be explained that the current responses of two metal ions can increase significantly with the increasing proportion of $\mathrm{M}-\gamma-\mathrm{Al}_{2} \mathrm{O}_{3}$ due to the properties of large surface area of the synthetic $\mathrm{M}-\gamma-\mathrm{Al}_{2} \mathrm{O}_{3}$.

\subsection{The proportion of liquid paraffin}

The modified proportion of liquid paraffin was adjusted gradually to study its effect on the current response of $\mathrm{Pb}^{2+}$ and $\mathrm{Cd}^{2+}$. The mass ratios of the solid mixture (graphite powder and $\mathrm{M}-\gamma$ $\mathrm{Al}_{2} \mathrm{O}_{3}$ ) to liquid paraffin was set as $5: 1,4: 1,3: 1,2: 1,1: 1$, respectively. The smaller amount of the liquid paraffin is used, the higher current responses of $\mathrm{Pb}^{2+}$ and $\mathrm{Cd}^{2+}$ can be achieved. If the proportion of added liquid paraffin is too small, the carbon paste could fall into the electrolyte. Good current responses and peak shapes of two metal ions can be achieved when the mass ratios of the solid mixture (graphite powder and $\mathrm{M}-\gamma-\mathrm{Al}_{2} \mathrm{O}_{3}$ ) to liquid paraffin is $3: 1$.

\subsection{The electrochemical property of $\mathrm{M}-\gamma-\mathrm{Al}_{2} \mathrm{O}_{3}-\mathrm{CPE}$}

Cyclic voltammetry (CV) and electrochemical impedance spectroscopy (EIS) measurements of $\mathrm{M}-\gamma-\mathrm{Al}_{2} \mathrm{O}_{3}$-CPE were performed in the solution of potassium ferricyanide (Fig. 5). As seen in Fig. 5A, the separation of redox peak potentials $\left(\Delta E_{\mathrm{p}}\right)$ at $\mathrm{M}-\gamma-$ $\mathrm{Al}_{2} \mathrm{O}_{3}$-CPE get smaller compared with BCPE. The current response of redox peak also increase greatly relative to the BCPE. These phenomena indicate that the modified $\mathrm{M}-\gamma-\mathrm{Al}_{2} \mathrm{O}_{3}$ can not only enlarge the specific surface area of the CPE but also promote the electron transfer. The charge transfer resistance $\left(R_{\mathrm{ct}}\right)$ of $\mathrm{M}-\gamma-\mathrm{Al}_{2} \mathrm{O}_{3}-\mathrm{CPE}$ (Fig. $5 \mathrm{~B}$ ) is quite smaller than that of EIS for BCPE. This result is consistent with the result of $\mathrm{CV}$ analysis.

\subsection{The voltammetric characteristics of $\mathrm{Pb}^{2+}$ and $\mathrm{Cd}^{2+}$ ion on $\mathrm{M}-\gamma-\mathrm{Al}_{2} \mathrm{O}_{3}-\mathrm{CPE}$}

Different pulse voltammetry (DPV) was employed to investigate the electrochemical behaviors of $\mathrm{Pb}^{2+}\left(10 \mu \mathrm{mol} \mathrm{L}^{-1}\right)$ and $\mathrm{Cd}^{2+}$ $\left(10 \mu \mathrm{mol} \mathrm{L}^{-1}\right)$ on $\mathrm{M}-\gamma-\mathrm{Al}_{2} \mathrm{O}_{3}$-CPE and BCPE. The buffer solution used in this system is HAc-NaAc $(\mathrm{pH}=4.5)$. The deposition potential and the deposition time of this system are $-1.0 \mathrm{~V}$ and $180 \mathrm{~s}$, respectively. As displayed in Fig. 6, sensitivity oxidation peaks of $\mathrm{Pb}^{2+}$ and $\mathrm{Cd}^{2+}$ can be observed at $-0.5 \mathrm{~V}$ and $-0.75 \mathrm{~V}$, respectively. The peak current responses of two metal ions enhance significantly in the presence of $\mathrm{M}-\gamma-\mathrm{Al}_{2} \mathrm{O}_{3}$ at carbon paste electrode (curve b) compared with BCPE (curve a) implying that the porous $\mathrm{M}-\gamma-\mathrm{Al}_{2} \mathrm{O}_{3}$ exhibits strong adsorption

Table 1 Analytical parameters for simultaneous determination of $\mathrm{Pb}^{2+}$ and $\mathrm{Cd}^{2+}$

\begin{tabular}{llll}
\hline Analyte & $\begin{array}{l}\text { Linear range } \\
(\mu \mathrm{mol} \mathrm{L})^{-1}\end{array}$ & Regression equation $i_{\mathrm{p}}{ }^{a}, C^{b}$ & $R^{2}$ \\
\hline $\mathrm{Pb}^{2+}$ & $0.001-10$ & $i_{\mathrm{p}}=11.349 C+0.1034$ & 0.9988 \\
$\mathrm{Cd}^{2+}$ & $0.01-10$ & $i_{\mathrm{p}}=3.4627 C+0.0006$ & 0.9971
\end{tabular}

${ }^{a} i_{\mathrm{p}}(\mu \mathrm{A})$ is the peak current. ${ }^{b} C\left(\mu \mathrm{mol} \mathrm{L}{ }^{-1}\right)$ is the concentration of the analyte. Electrochemical conditions are the same as Fig. 9. 
Table 2 Comparison of the response characteristics of different modified electrodes

\begin{tabular}{|c|c|c|c|c|c|}
\hline \multirow[b]{2}{*}{ Electrode materials } & \multicolumn{2}{|c|}{ Linear range $\left(\mu \mathrm{mol} \mathrm{L}{ }^{-1}\right)$} & \multicolumn{2}{|c|}{$\begin{array}{l}\text { Detection limit } \\
\left(\mathrm{nmol} \mathrm{L}^{-1}\right)\end{array}$} & \multirow[b]{2}{*}{ Reference } \\
\hline & $\mathrm{Pb}^{2+}$ & $\mathrm{Cd}^{2+}$ & $\mathrm{Pb}^{2+}$ & $\mathrm{Cd}^{2+}$ & \\
\hline Bi-xerogel/GCE ${ }^{a}$ & $0.0097-0.082$ & $0.0044-0.080$ & 6.3 & 3.3 & 32 \\
\hline $\mathrm{SNAC} / \mathrm{GCE}^{b}$ & $0.09-5.70$ & $0.09-4.8$ & 5.7 & 24.0 & 33 \\
\hline (C-Bi) nanocomposite/CPE ${ }^{c}$ & $0.0048-0.48$ & $0.0089-0.89$ & 2.9 & 5.3 & 34 \\
\hline SbNP/MWCNT/CPE ${ }^{f}$ & $0.048-0.29$ & $0.089-0.53$ & 3.1 & 6.9 & 37 \\
\hline CB-15-crown-5/GCE ${ }^{g}$ & $0.053-0.9$ & $0.14-1.7$ & 16.0 & 42.0 & 38 \\
\hline BiOCl/MWCNT/GCE ${ }^{h}$ & $0.024-0.24$ & $0.044-0.44$ & 2.8 & 11.0 & 39 \\
\hline L-cys/GR-CS/GCE ${ }^{i}$ & $0.05-0.30$ & $0.005-0.60$ & 2.2 & 1.1 & 40 \\
\hline $\mathrm{BiF}_{4} / \mathrm{CPE}^{j}$ & $0.097-0.48$ & $0.18-0.89$ & 5.8 & 87.0 & 41 \\
\hline ERGNO/Bi/SPE ${ }^{k}$ & $0.0048-0.29$ & $0.0089-0.53$ & 3.8 & 4.5 & 42 \\
\hline
\end{tabular}

to two metal ions and meanwhile the large surface areas of $\mathbf{M}-\gamma$ $\mathrm{Al}_{2} \mathrm{O}_{3}$ can accelerate the electron transfer.

\subsection{Optimization of detection parameters}

3.6.1 The supporting electrolyte and pH. Three kinds of buffer solution namely NaAc-HAc, britton-robinson and $\mathrm{Na}_{2} \mathrm{HPO}_{4}-\mathrm{NaH}_{2} \mathrm{PO}_{4}$ were tried to be used as the supporting electrolyte of detection system. The results show that better peak shape, resolution and sensitivity were achieved by using buffer solution of NaAc-HAc than that of britton-robinson and $\mathrm{Na}_{2} \mathrm{HPO}_{4}-\mathrm{NaH}_{2} \mathrm{PO}_{4}$. So NaAc-HAc buffer solution was selected as the supporting electrolyte for subsequent experiments.

The effects of pH values (NaAc-HAc buffer solution, $\mathrm{pH}$ 4.57.0) on the peak potential and peak currents of two metal ions are shown in Fig. 7. The peak potentials of two metal ions shift negatively with the increasing of $\mathrm{pH}$ values. Good linear relationships between the peak potentials of two metal ions and
$\mathrm{pH}$ values are obtained. The linear equations are $E_{\mathrm{pa}}(\mathrm{V})=$ $-0.4252-0.0149 \mathrm{pH}\left(R^{2}=0.9922\right)$ and $E_{\mathrm{pa}}(\mathrm{V})=-0.6532-$ $0.0184 \mathrm{pH}\left(R^{2}=0.9914\right)$ (inset $\left.\mathrm{B}\right)$, respectively. The peak currents of $\mathrm{Pb}^{2+}$ and $\mathrm{Cd}^{2+}$ firstly increases and then decreases with the increase of $\mathrm{pH}$ values (inset A). They achieve the maximum at $\mathrm{pH}$ 6.0. Therefore, $\mathrm{pH} 6.0$ was selected for further study.

3.6.2 The accumulation potential and accumulation time. The accumulation potential is an important parameter which can affect greatly on the sensitivity of determination for heavy metal ions. Fig. 8 shows the effect of accumulation potential on the peak current of $\mathrm{Pb}^{2+}$ and $\mathrm{Cd}^{2+}$ with accumulation potential ranging from $-0.7 \mathrm{~V}$ to $-1.2 \mathrm{~V}$. The peak currents of $\mathrm{Pb}^{2+}$ and $\mathrm{Cd}^{2+}$ can improve obviously with negative shifting of the accumulation potential. When the accumulation potential exceed to $-1.0 \mathrm{~V}$, the peak current of two metal ions begin to stabilize. Hence, the accumulation potential is fixed as $-1.0 \mathrm{~V}$.

Table 3 Results of the proposed method for the determination of $\mathrm{Pb}^{2+}$ and $\mathrm{Cd}^{2+}$ in various water samples $(n=3)^{a}$

\begin{tabular}{|c|c|c|c|c|}
\hline Sample & Analytes & Added $\left(\mathrm{nmol} \mathrm{L}^{-1}\right)$ & Found $\left(\mathrm{nmol} \mathrm{L}^{-1}\right)$ & Recovery (\%) \\
\hline \multirow[t]{3}{*}{ Tap water } & $\mathrm{Pb}^{2+}$ & 0 & $21.67 \pm 0.15$ & \\
\hline & & 20 & $40.52 \pm 0.66$ & 97.24 \\
\hline & & 50 & $59.51 \pm 0.79$ & 102.3 \\
\hline \multirow[t]{2}{*}{ Lake water } & $\mathrm{Pb}^{2+}$ & 0 & $41.22 \pm 0.86$ & \\
\hline & & 20 & $63.63 \pm 1.09$ & 103.94 \\
\hline
\end{tabular}

${ }^{a}$ Electrochemical conditions are the same as Fig. 9. 
The accumulation time is also another parameter which can apparently influence the detection sensitivities of $\mathrm{Pb}^{2+}$ and $\mathrm{Cd}^{2+}$. With the increase of accumulation time, the peak currents of $\mathrm{Pb}^{2+}$ and $\mathrm{Cd}^{2+}$ noticeably increase at first and then decrease gradually after reaching the peak value. In addition, the accumulation time beyond $360 \mathrm{~s}$ might result in the distortions of signals for these two metal ions. These results might be explained that the adsorptions of $\mathrm{Pb}^{2+}$ and $\mathrm{Cd}^{2+}$ on the surface of $\mathrm{M}-\gamma-\mathrm{Al}_{2} \mathrm{O}_{3}$-CPE attain a saturation level. So $360 \mathrm{~s}$ is considered to be the accumulation time in this work.

\subsection{Analytical performances of $\mathbf{P b}^{2+}$ and $\mathrm{Cd}^{2+}$}

Under the optimum conditions, the determinations of $\mathrm{Pb}^{2+}$ and $\mathrm{Cd}^{2+}$ were conducted at $\mathrm{M}-\gamma-\mathrm{Al}_{2} \mathrm{O}_{3}$-CPE using DPV method. As described in Fig. 9 and 10, good linear correlation could be found between the peak currents and the concentrations of $\mathrm{Pb}^{2+}$ and $\mathrm{Cd}^{2+}$. The regression equations, linear response ranges and detection limits are summarized in Table 1. Compared with previous literatures (Table 2), improved or comparable performances have been achieved for the determinations of $\mathrm{Pb}^{2+}$ and $\mathrm{Cd}^{2+}$ using $\mathrm{M}-\gamma-\mathrm{Al}_{2} \mathrm{O}_{3}-\mathrm{CPE}$.

In order to verify the reproducibility, stability and antiinterference performance of $\mathrm{M}-\gamma-\mathrm{Al}_{2} \mathrm{O}_{3}-\mathrm{CPE}$, the measurements were carried out in a NaAc-HAc buffer solution ( $\mathrm{pH}$ 6.0) containing $1.0 \mu \mathrm{mol} \mathrm{L} \mathrm{L}^{-1} \mathrm{~Pb}^{2+}$ and $1.0 \mu \mathrm{mol} \mathrm{L}{ }^{-1} \mathrm{Cd}^{2+}$. The reproducibility was evaluated by 8 continuous measurements of peak currents for $\mathrm{Pb}^{2+}$ and $\mathrm{Cd}^{2+}$. RSDs of the peak currents are $3.5 \%$ and $4.3 \%$, respectively. At the same time, five modified carbon paste electrodes were prepared and examined in the same conditions, RSDs of the peak currents are $3.2 \%$ and $4.8 \%$, respectively. The $\mathrm{M}-\gamma-\mathrm{Al}_{2} \mathrm{O}_{3}$-CPE was polished by a weighting paper and then eluted by distilled water. The treated electrode was dried and stored in a $4{ }^{\circ} \mathrm{C}$ refrigerator. After 7 days, the stripping peak currents for $1.0 \mu \mathrm{mol} \mathrm{L}{ }^{-1} \mathrm{~Pb}^{2+}$ and $1.0 \mu \mathrm{mol} \mathrm{L}^{-1}$ $\mathrm{Cd}^{2+}$ decrease by $6.2 \%$ and $7.4 \%$, respectively. These experimental results indicate that the $\mathrm{M}-\gamma-\mathrm{Al}_{2} \mathrm{O}_{3}-\mathrm{CPE}$ exhibit good reproducibility and stability. Interference experiment was also investigated by adding general coexistence ions to a solution containing $1.0 \mu \mathrm{mol} \mathrm{L}{ }^{-1} \mathrm{~Pb}^{2+}$ and $1.0 \mu \mathrm{mol} \mathrm{L}{ }^{-1} \mathrm{Cd}^{2+}$ in a NaAcHAc buffer solution ( $\mathrm{pH}$ 6.0). No evident interference can be found for the determinations of $\mathrm{Pb}^{2+}$ and $\mathrm{Cd}^{2+}$ in the presence of $\mathrm{Na}^{+}\left(1000 \mu \mathrm{mol} \mathrm{L}{ }^{-1}\right), \mathrm{K}^{+}\left(1000 \mu \mathrm{mol} \mathrm{L}{ }^{-1}\right), \mathrm{Cl}^{-}(1000 \mu \mathrm{mol}$ $\left.\mathrm{L}^{-1}\right), \mathrm{Br}^{-}\left(1000 \mu \mathrm{mol} \mathrm{L}{ }^{-1}\right), \mathrm{F}^{-}\left(1000 \mu \mathrm{mol} \mathrm{L}^{-1}\right), \mathrm{Al}^{3+}(500 \mu \mathrm{mol}$ $\left.\mathrm{L}^{-1}\right), \mathrm{Mg}^{2+}\left(500 \mu \mathrm{mol} \mathrm{L}{ }^{-1}\right), \mathrm{Ca}^{2+}\left(500 \mu \mathrm{mol} \mathrm{L}{ }^{-1}\right), \mathrm{Zn}^{2+}(500 \mu \mathrm{mol}$ $\left.\mathrm{L}^{-1}\right)$ and $\mathrm{Mn}^{2+}\left(500 \mu \mathrm{mol} \mathrm{L}{ }^{-1}\right)$ and $\mathrm{Fe}^{3+}\left(50 \mu \mathrm{mol} \mathrm{L}{ }^{-1}\right)$ with a maximum allowable error of $5.0 \%$. In addition, $\mathrm{Cu}^{2+}$ can interfere with the detection of $\mathrm{Cd}^{2+}$, which can compete with $\mathrm{Cd}^{2+}$ to reduce on the electrode surface.

\subsection{Application}

To evaluate the application of the proposed $\mathrm{M}-\gamma-\mathrm{Al}_{2} \mathrm{O}_{3}-\mathrm{CPE}$, it was used to analyze the concentrations of $\mathrm{Pb}^{2+}$ and $\mathrm{Cd}^{2+}$ in artificial lake water and tap water samples. The supernatant liquid of artificial lake water and the tap water were collected and diluted 5 times by $0.1 \mathrm{~mol} \mathrm{~L}^{-1} \mathrm{NaAc}-\mathrm{HAc}$ buffer solution $(\mathrm{pH}$ 6.0). The treated water samples were determined by $\mathbf{M}-\gamma-$
$\mathrm{Al}_{2} \mathrm{O}_{3}$-CPE under the optimal experimental conditions. The results are listed in Table 3. The recoveries for these two metal ions are between $97.24 \%$ and $103.94 \%$. The water samples were also detected by conventional atomic absorption spectrometry (AAS, WFX-130A, Beijing Rayleigh Analytical Instrument Corp. Ltd.) method. The concentrations of $\mathrm{Pb}^{2+}$ and $\mathrm{Cd}^{2+}$ were $21.58 \pm$ 0.19 and $8.23 \pm 0.11 \mathrm{nmol} \mathrm{L}^{-1}$ in tap water, respectively; while those of lake water are $41.67 \pm 0.52$ and $37.32 \pm 0.61 \mathrm{nmol} \mathrm{L}^{-1}$, respectively. The measuring results obtained by these two methods are basically the same, indicating a good reliability of the proposed methods.

\section{Conclusion}

In present work, aniline was chosen as an interface protective agent to prepare large surface area $\mathrm{M}-\gamma-\mathrm{Al}_{2} \mathrm{O}_{3}$ which possess a large surface area and a narrow pore-size distribution. The $\mathrm{M}$ $\gamma-\mathrm{Al}_{2} \mathrm{O}_{3}$ was modified into the carbon paste to fabricate a novel $\mathrm{M}-\gamma-\mathrm{Al}_{2} \mathrm{O}_{3}$-CPE. The proposed electrode has a high sensitivity, stability and reproducibility in the presence of $\mathrm{M}-\gamma-\mathrm{Al}_{2} \mathrm{O}_{3}$. The electrode exhibits excellent performance for the detections of $\mathrm{Pb}^{2+}$ and $\mathrm{Cd}^{2+}$ in artificial lake water and tap water samples. The developed method will have extensive potential in the field of environmental monitoring.

\section{Conflicts of interest}

There are no conflicts to declare.

\section{Acknowledgements}

The authors are grateful to the support of Natural Science Foundation of China (21643001), the Scientific Research Fund of Natural Science Foundation of Fujian Province (2015J01081, 2015J05019), the China Postdoctoral Science Foundation (2017M612106) and the Opening Foundation of National Engineering Research Center for Sugarcane (PTJH1500114).

\section{References}

1 T. Kemper and S. Sommer, Estimate of heavy metal contamination in soils after a mining accident using reflectance spectroscopy, Environ. Sci. Technol., 2002, 36, 2742-2747.

2 J. Chang, G. Zhou, E. R. Christensen, R. Heideman and J. Chen, Graphene-based sensors for detection of heavy metals in water: a review, Anal. Bioanal. Chem., 2014, 406, 3957-3975.

3 G. Aragay and A. Merkoci, Nanomaterials application in electrochemical detection of heavy metals, Electrochim. Acta, 2012, 84, 49-61.

4 J. Y. Zhang, J. L. Fang and X. C. Duan, Determination of cadmium in water samples by fast pyrolysis-chemical vapor generation atomic fluorescence spectrometry, Spectrochim. Acta, 2016, 122, 52-55.

5 H. Luo, X. Y. Wang, R. Dai, Y. Liu, X. Jiang, X. L. Xiong and K. Huang, Simultaneous determination of arsenic and 
cadmium by hydride generation atomic fluorescence spectrometry using magnetic zero-valent iron nanoparticles for separation and pre-concentration, Microchem. J., 2017, 133, 518-523.

6 A. A. Shaltout, J. Boman, B. Welz, I. N. B. Castilho, E. A. Al Ashkar and S. M. Gaita, Method development for the determination of $\mathrm{Cd}, \mathrm{Cu}, \mathrm{Ni}$ and $\mathrm{Pb}$ in PM 2.5 particles sampled in industrial and urban areas of Greater Cairo, Egypt, using high-resolution continuum source graphite furnace atomic absorption spectrometry, Microchem. J., 2014, 113, 4-9.

7 H. Bagheri, A. Afkhami, M. Saber-Tehrani and H. Khoshsafar, Preparation and characterization of magnetic nanocomposite of Schiff base/silica/magnetite as a preconcentration phase for the trace determination of heavy metal ions in water, food and biological samples using atomic absorption spectrometry, Talanta, 2012, 97, 87-95.

8 M. L. Lin and S. J. Jiang, Determination of As, $\mathrm{Cd}, \mathrm{Hg}$ and $\mathrm{Pb}$ in herbs using slurry sampling electrothermal vaporisation inductively coupled plasma mass spectrometry, Food Chem., 2013, 141, 2158-2162.

9 R. P. Lamsal and D. Beauchemin, Estimation of the bioaccessible fraction of $\mathrm{Cr}$, $\mathrm{As}, \mathrm{Cd}$ and $\mathrm{Pb}$ in locally available bread using on-line continuous leaching method coupled to inductively coupled plasma mass spectrometry, Anal. Chim. Acta, 2015, 867, 9-17.

10 Q. X. Zhou, M. Lei, Y. L. Liu, Y. L. Wu and Y. Y. Yuan, Simultaneous determination of cadmium, lead and mercury ions at trace level by magnetic solid phase extraction with Fe@Ag@dimercaptobenzene coupled to high performance liquid chromatography, Talanta, 2017, 175, 194-199.

11 P. D. Schumacher, K. A. Fitzgerald, J. O. Schenk and S. B. Clark, Preconcentration off-elements from aqueous solution utilizing a modified carbon paste electrode, Anal. Chem., 2011, 83, 1388-1393.

12 I. Svancara, K. Vytras, K. Kalcher, A. Walcarius and J. Wang, Carbon paste electrodes in facts, numbers, and notes: a review on the occasion of the 50-years jubilee of carbon paste in electrochemistry and electroanalysis, Electroanalysis, 2009, 21, 7-28.

13 A. Afkhami, T. Madrakian, H. Ghaedi and H. Khanmohammadi, Construction of a chemically modified electrode for the selective determination of nitrite and nitrate ions based on a new nanocomposite, Electrochim. Acta, 2012, 66, 255-264.

14 B. B. Yan, W. Q. Li, J. Y. Tao, N. G. Xu, X. P. Li and G. Y. Chen, Hydrogen production by aqueous phase reforming of phenol over Ni/ZSM-5 catalysts, Int. J. Hydrogen Energy, 2017, 42, 6674-6682.

15 J. B. Raoof, F. Chekin and V. Ehsani, Palladium-modified mesoporous silica SBA-15 modified in carbon-paste electrode as a sensitive voltammetric sensor for detection of oxalic acid, Sens. Actuators, B, 2015, 207, 291-296.
16 R. Oord and B. M. Weckhuysen, Chapter $10-\mathrm{Cu}$-Zeolite Selective Catalytic Reduction Catalysts for $\mathrm{NO}_{x}$ Conversion, Zeolites Zeolite-Like Mater., 2016, 433-450.

17 B. Bardakci and S. Bahceli, Adsorption of $n$-propyl mercaptan on Pb/LTA zeolites, Prot. Met. Phys. Chem. Surf., 2013, 49, 455-459.

18 J. Y. Sun, T. Gan, Y. P. Deng, Z. X. Shi and Z. Lv, Pt nanoparticles-functionalized hierarchically porous $\mathrm{Al}_{2} \mathrm{O}_{3}$ hollow spheres based electrochemical sensor for ultrasensitive guaiacol detection, Sens. Actuators, B, 2015, 211, 339-345.

19 V. Jayaraman, E. Prabhu, A. Sree Rama Murthy, P. C. Clinsha, K. I. Gnanasekar and T. Gnanasekaran, Na- $\beta-\mathrm{Al}_{2} \mathrm{O}_{3}$ based sensor for sodium aerosol, Sens. Actuators, B, 2014, 202, 913.

20 J. J. Yu, J. R. Ma, F. Q. Zhao and B. Z. Zeng, Direct electrontransfer and electrochemical catalysis of hemoglobin immobilized on mesoporous $\mathrm{Al}_{2} \mathrm{O}_{3}$, Electrochim. Acta, 2007, 53, 1995-2001.

21 K. L. Martena, S. M. Grant and M. Jaroniec, Poly(ethylene oxide)-poly(butylene oxide)-poly(ethylene oxide)-templated synthesis of mesoporous alumina: effect of triblock copolymer and acid concentration, ACS Appl. Mater. Interfaces, 2012, 4, 3738-3744.

22 A. Mitra, D. Jana and G. De, Facile synthesis of hexagonally ordered mesoporous aluminum oxide thin films with high catalytic activity, Microporous Mesoporous Mater., 2012, 158, 187-194.

23 S. M. Grant and M. Jaroniec, Effect of acid concentration on pore size in polymer-templated mesoporous alumina, $J$. Mater. Chem., 2012, 22, 86-92.

24 X. L. Zheng, Q. P. Sun, F. Liu, Y. Zheng and J. B. Weng, Effect of p-aminobenzoic on synthesizing ordered mesoporous alumina via the sol-gel method, J. Porous Mater., 2014, 21, 819-825.

25 F. Huang, Y. Zheng, G. H. Cai, Y. Zheng, Y. H. Xiao and K. M. Wei, A new synthetic procedure for ordered mesoporous-alumina with a large surface area, Scr. Mater., 2010, 63, 339-342.

26 F. Pan, X. C. Lu, T. Wang, Y. Wang, Z. M. Zhang, Y. Yan and S. P. Yang, Synthesis of large-mesoporous $\mathrm{Al}_{2} \mathrm{O}_{3}$ from coalseries kaolin at room temperature, Mater. Lett., 2013, 91, 136-138.

27 Q. Yuan, A. X. Yin, C. Luo, L. D. Sun, Y. W. Zhang, W. T. Duan, H. C. Liu and C. H. Yan, Facile synthesis for ordered mesoporous $\gamma$-aluminas with high thermal stability, J. Am. Chem. Soc., 2008, 130, 3465-3472.

28 Q. L. Wu, F. Zhang, J. P. Yang, Q. Li, B. Tu and D. Y. Zhao, Synthesis of ordered mesoporous alumina with large pore sizes and hierarchical structure, Microporous Mesoporous Mater., 2011, 143, 406-412.

29 Q. Sun, Y. Zheng, Z. H. Li, Y. Zheng, Y. H. Xiao and G. H. Cai, Synthesis of ordered mesoporous $\gamma$-alumina influenced by the interfacial protector, Mater. Lett., 2012, 84, 44-47.

30 Q. Sun, Y. Zheng, Z. H. Li, Y. Zheng, Y. H. Xiao, G. H. Cai and K. M. Wei, Studies on the improved thermal stability for 
doped ordered mesoporous $\gamma$-alumina, Phys. Chem. Chem. Phys., 2013, 15, 5670-5676.

31 Q. Yuan, H. H. Duan, L. L. Li, Z. X. Li, W. T. Duan, L. S. Zhang, W. G. Song and C. H. Yan, Homogeneously dispersed ceria nanocatalyst stabilized with ordered mesoporous alumina, Adv. Mater., 2010, 22, 1475-1478.

32 P. A. Dimovasilis and M. I. Prodromidis, Bismuth-dispersed xerogel-based composite films for trace $\mathrm{Pb}(\mathrm{II})$ and $\mathrm{Cd}(\mathrm{II})$ voltammetric determination, Anal. Chim. Acta, 2013, 769, 49-55.

33 R. Madhu, K. V. Sankar, S. M. Chen and R. K. Selvan, Ecofriendly synthesis of activated carbon from dead mango leaves for the ultrahigh sensitive detection of toxic heavy metal ions and energy storage applications, RSC Adv., 2014, 4, 1225-1233.

34 M. Gich, C. Fernandez-Sanchez, L. C. Cotet, P. Niu and A. Roig, Facile synthesis of porous bismuth-carbon nanocomposites for the sensitive detection of heavy metals, J. Mater. Chem. A, 2013, 1, 11410-11418.

35 P. K. Sahoo, B. Panigrahy, S. Sahoo, A. K. Satpati, D. Li and D. Bahadur, In situ synthesis and properties of reduced graphene oxide/Bi nanocomposites: as an electroactive material for analysis of heavy metals, Biosens. Bioelectron., 2013, 43, 293-296.

$36 \mathrm{H}$. Lin, M. Li and D. Mihailovič, Simultaneous determination of copper, lead, and cadmium ions at a $\mathrm{Mo}_{6} \mathrm{~S}_{9-x} \mathrm{I}_{x}$ nanowires modified glassy carbon electrode using differential pulse anodic stripping voltammetry, Electrochim. Acta, 2015, 154, 184-189.

37 A. M. Ashrafi, S. Cerovac, S. Mudrić, V. Guzsvány, L. Husáková, I. Urbanová and K. Vytřas, Antimony nanoparticle-multiwalled carbon nanotubes composite immobilized at carbon paste electrode for determination of trace heavy metals, Sens. Actuators, B, 2014, 191, 320-325.
38 N. Serrano, A. González-Calabuig and M. del Valle, Crown ether-modified electrodes for the simultaneous stripping voltammetric determination of $\mathrm{Cd}(\mathrm{II}), \mathrm{Pb}(\mathrm{II})$ and $\mathrm{Cu}(\mathrm{II})$, Talanta, 2015, 138, 130-137.

39 S. Cerovac, V. Guzsvány and Z. Kónya, Trace level voltammetric determination of lead and cadmium in sediment pore water by a bismuth-oxychloride particlemultiwalled carbon nanotube composite modified glassy carbon electrode, Talanta, 2015, 134, 640-649.

40 W. Zhou, C. Li, C. Sun and X. Yang, Simultaneously determination of trace $\mathrm{Cd}^{2+}$ and $\mathrm{Pb}^{2+}$ based on l-cysteine/ graphene modified glassy carbon electrode, Food Chem., 2016, 192, 351-357.

41 H. Sopha, L. Baldrianová and E. Tesařová, A New Type of Bismuth Electrode for Electrochemical Stripping Analysis Based on the Ammonium Tetrafluorobismuthate BulkModified Carbon Paste, Electroanalysis, 2010, 22, 1489-1493.

42 J. Ping, Y. Wang, J. Wu and Y. Ying, Development of an electrochemically reduced graphene oxide modified disposable bismuth film electrode and its application for stripping analysis of heavy metals in milk, Food Chem., 2014, 151, 65-71.

43 L. L. Xiao, B. W. Wang, L. Ji, Q. H. Yuan, G. Z. Hu, A. G. Dong and W. Gan, An efficient electrochemical sensor based on three-dimensionally interconnected mesoporous graphene framework for simultaneous determination of $\mathrm{Cd}(\mathrm{II})$ and $\mathrm{Pb}(\mathrm{II})$, Electrochim. Acta, 2016, 222, 1371-1377.

44 D. Riman, D. Jirovsky, J. Hrbac and M. I. Prodromidis, Green and facile electrode modification by spark discharge: bismuth oxide-screen printed electrodes for the screening of ultra-trace $\mathrm{Cd}(\mathrm{II})$ and $\mathrm{Pb}(\mathrm{II})$, Electrochem. Commun., 2015, 50, 20-23. 